\section{The Language Acquisition Approaches and the Development of Literacy Skills in Children}

\author{
Ahmet Çakıroğlu*
}

\begin{tabular}{ll}
\hline Received: & 22 September 2018 \\
Revised: $\quad 24$ November 2018 \\
Accepted: $\quad 27$ December 2018 \\
ISSN: 1307-9298 \\
Copyright @ IEJEE \\
www.iejee.com
\end{tabular}

DOI: 10.26822/iejee.2019248600

\begin{abstract}
The purpose of this study is to examine the language acquisition approaches whose conceptions of language acquisitions are transferred to learning environments through adjustments made on the basis of application methods. The paper also discussed their similarities and differences. Different approaches to language acquisition in various disciplines, different views, and perceptions of it have been developed. There are some approaches completely distinct from others, while there are some others affected by different perspectives. In addition to the language acquisition approaches mentioned above, the paper delineated what literacy skills are and what kind of hierarchical order is followed by the development of these skills. The study, on one hand, deliberated children's innate abilities and their acquired skills. by examining the reading and writing methods and from which approach they have been affected. The study, on the other hand, summarized the views of Vygotsky, whose contributions to learning in general and language acquisition in particular are better understood today. In brief, this paper discusses and explains the language acquisition approaches and the development process of children's literacy skills.
\end{abstract}

Keywords: Language Acquisition, Language Acquisition Approaches, Development Of Literacy Skills In Children

\section{Introduction}

Literacy skills are of vital importance for all people and enable children to get to know the life and interact with their environment and other people, leading the way to a successful career. Starting primary school is certainly a new chapter and an exciting step for both students and their families. First-grade students attending elementary school which is the beginning of a tiring process for both teachers and students, are equipped with the speaking skill that is the most natural communication tool in a language. The hearing and speaking skills, which are essential for teaching, are two basic elements of basic language skills and they have an important role in the acquisition of two other basic skills of reading and writing. How to inculcate literacy skills in children and what methods and techniques should be applied have been tried several times for these techniques to be implemented and today new applications have been particularly implemented on the basis of learning theories. It has been observed that though conducting different methods harbour some weaknesses and strengths in comparison to others, they all lead to inculcation of literacy skills in students, whether in a short or long time, whether in a more or less meaningful way.

Reading and writing are not only two important learning domains but also two important language skills. Hence, variables such as intelligence, environment, individual differences, and readiness for learning that affect learning are also effective on the acquisition of the above-mentioned skills. Every student starts the school with his/her own learning capacity, environmental and communicative prior knowledge and level of competence and builds new knowledge on them. In this process, some students make great strides in learning while other make by slow degrees. Sometimes some children need more adult supervision and assistance than others for various reasons.

The question of "Does the acquisition of literacy skills start before children start primary school?" has led researchers working in the field to conduct a great deal of research. Some children development theorists or linguists claim that the acquisition of literacy skills is a process beginning in the womb. There are several views on the issue of the acquisition of literacy skills expressed by both the linguists arguing that language skills are innate skills and by the researchers claiming that they are acquired later in the life. In this part of the paper, the basic language acquisition approaches providing instructional perspectives in relation to how to inculcate literacy skills in children will be discussed briefly. Despite the fact that some theories have come to the fore from time to time to explain how children acquire a language skill. There are three pivot approaches to this issue dominating the literature which are the behaviourist, the linguistic, and the interactionist approaches (Maviş, 2007). The following section provides the brief descriptions of the approaches.

\section{The Behaviourist Approach}

The behaviourist approach was founded and promoted by J. B. Watson. Its philosophical ground was laid by John Locke and physiological ground was laid by I. P. Pavlov while psychological ground was laid by E. L. Thorndike, B. F. Skinner, Hull, and L. L. Bernard (Ersanlı, 2012).

The behaviourists assert that, the subject of psychology is behaviours and they can be measured and evaluated only by objective methods. In this context, no behaviour that is not objective, can be proved, objectively measured and evaluated is worth investigating. The reason why the behaviourists refused internal experiences is that they believe they could not be measured by scientific methods. These theorists who are also known as stimulus-response psychologists have primarily focused on the examination of the responses occurring in the organism as a result of the stimuli. The behaviourists who assumed and treated the human mind as the black box are interested in stimulus and response, not what is happening in the black box. 
What is controllable and measurable is what input enters to the box and what output exits from the box, it is not measurable what is happening inside the box. The study of Skinner (1957) named Verbal Behaviour, postulates the existence of human biological abilities (e.g. initial potential-speech) though he claims that there is no other language-related factor other than these. Skinner (1957) lays weight on that there is no need for any new principles of language acquisition. He believes that language is a learned skill and just a verbal behaviour. He argues that humans only use but do not own the language (Maviş, 2007).

Skinner (1957) claims that all human behaviours, including language skills, have no significant difference with compared to any other behaviour like brushing teeth that can be learned by experience. According to this approach, the language is regarded as an instrument employed in animal training by way of imitation, conditioning, and reinforcement. Hence, language is a verbal behaviour learned within the framework of conditioning. According to this definition, children's language; that is, their verbal behaviour, is a form of selectively fortified non-stereotyped vocalizations producing appropriate results in certain environments over time (Owens, 2001, Maviş, 2007)

The behaviourist approach claims that children are passive and the environment is active in language learning process. Every child comes into the world with an empty language tank and as the time progresses he/she lives with language models he/she sees around, he/she fills this tabula rasa through the experiences and the child becomes a user of the language (Maviş, 2007; Greene \& Petty, 1975).

Children start to use the phonemes they are exposed to the surroundings by imitating them. Sounds and syllables that are not repeated and used or not adequately reinforced tend to get lost over time. In the behaviourist approach, they fade away. Words made up of sounds that are reinforced and frequently repeated with the help of parents or adults around are added to the vocabulary of the child; on the contrary, those which are not reinforced or repeated tend to disappear. In brief, the words that are modelled through conditioned stimuli are learned by the child (Maviş, 2007).

Although there are many criticisms on the behaviourist theories, predominantly levelled by linguistic approaches, the idea that the language is learned in the environment in which the child was born has then affected many scientists advocating socio-cultural view of language like Vygotsky (1962). The adaptation of the behaviourist approach to teaching of reading and writing has occurred in the form of children's voicing the written units they have seen under the guidance of the teacher and disintegrating the sentence into its units (words/syllables) to make sense of it. This method called "Tag Method" was employed as a way in the initial teaching of reading and writing in Turkey until recently and many adults in today learned reading and writing through this method.

\section{The Linguistic Approach}

The behaviourists' argument projecting that language is not an innate but a learned phenomenon was opposed by researchers having the linguistic view of language also known as the innatist levelling serious criticisms against it.

$\mathrm{N}$. Chomsky, one of the linguistic theorists whose ideas have been widely adopted, and many other linguist scientists adopted the opinion that language is a human-specific fact and cannot be learned by other creatures. Language is claimed to be a biological-based phenomenon for humans and humans are regarded to have an innate readiness and competence to learn language. Chomsky (1967) defines this process as Language Acquisition Device (LAD) which is also called "the black box" in the literature (Maviş, 2007, Plante \& Beeson, 1999). According to this approach, the child's words are passed through a neural structure called the language mechanism and the child, who is constantly exposed to the same process with the effect of the environment, will gain grammatical competence as a result. Children bring out their potential on biological language through trial and error learning. In other words, by taking the structures they are exposed to from their parents and environment as an example, they create structures from simple sentences in the "subject-verb-object" order. In the context of language acquisition of children, the two structures that compose the sentences are deep and surface structures (Chomsky, 1967). The surface structure of the sentence is composed of words while the deep structure of the sentence consists of the meanings of words and sentences (Maviş, 2007; Gleitman, Osherson \& Liberman, 1995).

The linguistic approach advocating the exactly opposing view of the behaviourist approach defends the idea that children have a language at birth, bring out their potentials over time and form their language skills in a process. Since they overlooked the cognitive, social, and environmental factors they have been widely criticized. In a similar manner, this approach has been most severely criticized as it does not focus on the meaning rather on the sentence structure. This view, which does not have any aspect that can influence initial reading and writing processes or cannot add anything to instructional attempts, has mostly focused on the subjects of the adult language.

\section{The Interactionist Approaches}

The interactionist approaches comprise Developmental Cognitive Theory associated with Piaget (1971), Information Processing Theory, and Competitive Model. In addition, many other models and views along with the socio-cultural view of Vygotsky (1978b), have an important place in language acquisition. Here, mostly the ideas of Piaget (1926) and Vygotsky (1962) have been promoted as they have instructional applications for the inculcation of initial reading and writing skills in children.

The aforementioned linguistic and behaviourist views put forward opposite ideas in language acquisition., Even though they are opposed to each other, they both have strengths and weaknesses. They also put forward views that have been adopted as instructional methods in language learning. According to Maviş (2007), as implied by its name, interactionists have followed a conciliatory path by emphasizing the common and strong sides and suggestions of both behaviourists and linguists. The interactionists argue that several factors such as social, linguistic, biological, and cognitive elements affect the development process and they influence and foster each other. Cognitive and social factors improve language acquisition, in turn, language acquisition improves social and cognitive skills.

\section{Developmental Cognitive Theory}

J. Piaget is the most well-known interactionist creating the Developmental Cognitive Theory. Piaget (1971) defines the period from birth up to 18th month as the period in which a sensory-motor intelligence develops while explaining the children's mental stages of development. According to Piaget (1926), this phase is assumed to be a pre-language stage, since children in this period cannot use symbols representing objects around them. In this period, children try to understand directly objects with their senses (sensory) and their (motor) activities based on these senses. Children may not be able to distinguish objects from their practises apart from the ones they experienced (Maviş, 2007). Given 
the fact that even they cannot see the objects, they can still be present, not lost, children start to use symbols that represent them. Hence, these symbols become the first words they use. This process of representation constitutes the beginning of the language development (Atkinson et al., 2010). Piaget (1973), on the other hand, emphasizes that language and thought are closely related to each other. Language means cognition. Thinking is the most important tool of learning for humans. Each individual comes to the world equipped with abilities to form schemes, internalize, adapt, organize, and reconcile. Cognition relies on thinking, learning, and recall processes. Cognitive development occurs through experiences, social transitions, maturation, and balancing over time.

\section{Vygotsky's Socio-cultural Approach}

L. Vygotsky is a scientist with Socialist Marxist thought and tries to apply his views to the field of language and development. He has psychology, philosophy, literature, and law degrees. According to Vygotsky (1987), the social environment is a concept that facilitates child development and learning (Tudge \& Scrimsher, 2003).

Vygotsky (1978a) believes that children gain various concepts, ideas, attitudes, and facts through the influences of the social environment. The social environment in which a child is born and where he/she lives is effective in determining the nature and the type of interaction and communication that he/she will establish. Vygotsky (1962) claims that tools such as language, number, and art are the tools of the culture for understanding, regulating, and transmitting the thought. Vygotsky $(1962,1998)$ claims that children are basically capable of thinking and speaking. In his context, these capacities have become integrated into the internal conversation in children at around two years of age and this internal conversation is regarded as the child's private speech (Vygotsky, 1962, 1998). This process is the child's process of internalizing thoughts, knowledge, ideas and now the child tends to think rather than voice.

Vygotsky (1978) advocates that the nature of learning emerges as a natural consequence of the effective interaction and social communication with the environment. Adults and teachers, as the role models for children, speak with them, answer their inquiries and questions and provide the necessary learning assistance they need.

Activities carried out together with the children and assistance and support provided in this process allow them to solve the small problems that they could not solve initially which is his called the Zone of Proximal Development (ZPD). The ZPD is defined as "the distance between the actual developmental level as determined by independent problem solving and the level of potential development as determined through problem solving under an adult guidance or in collaboration with more capable peers" (Vygotsky, 1978b). The ZPD represents the volume of learning that a student can achieve when appropriate educational conditions and support are provided (Puntambekar \& Hübscher, 2005). In the ZPD concept, a teacher and a student (an adult and a child or a master and an apprentice) work together on a problem that the student cannot solve on his own or on a task that the student cannot complete on his/her own due to the degree of difficulty. Bruner (1984) asserts that the ZPD is an activity of Marxist thought requiring the more talented or more knowledgeable ones to share their knowledge and abilities with those less talented or less knowledgeable to accomplish a task. As seen from the perspective of attaining literacy skills, it is clear that assistance provided by teachers, specialized peers, conscious and knowledgeable adults for children in this process will lead to some significant instructional gains in the ZPD. The concept of decreasing and ending the assistance and support in the ZPD over time and in quantity is often confused with the concept of scaffolding, which is highlighted by the participatory modelling technique of Bandura (1977). These two concepts are combined by Wood, Bruner, and Ross (1976). supporting his/her cognitive processes In the ZPD, support or assistance provided by a teacher or an adult means speaking with students, asking questions, and giving them guidance (Vygotsky, 1987). This support students' cognitive processes (Wood, Bruner \& Ross, 1976).

As a consequence, since students become more specialized, cognitive support is reduced so that they take the responsibility on their own, that is, the teacher creates a ZPD and scaffolding for students so that they can be successful here.

The cognitive support provided for children in terms of the process of acquiring literacy skills and the area of the ZPD to be established are especially important for students having difficulty in acquiring these skills. Since teaching one to one is a challenging issue and time-consuming, especially in overcrowded classrooms, it is required to devote more time to ease the process. The importance of, creating a cooperative learning environment for students with different skill levels emphasised here is consistent with the Vygotsky's cooperative learning approach.

Vygotsky (1978b) thinks that all higher order cognitive skills are shaped by the social environment. Language is the one important element that affects it. As a result, Vygotsky (1978b) emphasizes the importance of social interaction in both explaining the basic concepts of learning and communicating his views on the language acquisition. He states that the language is one of the most important means of human development and cultural transmission. In Vygotsky's (1962) context, language develops from social conversations to private conversations and internal conversations. Scaffolding for children development improves their ability to make more individual activities on their own and empowers their cognitive developments.

Vygotsky died at a very young age with a great deal of scientific research; however for a long time his studies were not recognized and published in the West. His criticisms levelled against Piaget's thoughts were popularized later and his own thoughts were overshadowed. Here what is emphasized more is instructional practices rather than creating a conception of a comprehensive theoretical context such as learning is a cultural-historical transfer. One of the main instructional viewpoints he left behind is students-teacher interaction.

\section{Development of Children's Literacy Skills}

Literacy skills are important language skills affecting the development of humanity. In general, language skills are primary mental gains that distinguish human beings from other creatures. One of the most discussed issues in the education literature is language development.

The answer to the following questions of "how does the child learn in general" and "how does the child learn reading and writing as a learning area in particular" has been sought on the basis of the body of scientific knowledge accumulated from past to present. The difference between present and past can be defined as novelties and developments in correspondence with the age. It is known that many factors such as the potential for language abilities of the child formed before the birth in the mother's womb, their interactions with the environment, the impact of mental and developmental progress, and general learning efforts are effective in acquiring literacy skills. The following 
questions of 'when children are ready to acquire their literacy skills', 'how these skills should be acquired', 'how reading and writing acquisition processes progress' have always been asked and have been attempted to be answered in the light of various opinions, approaches, and theories. The acquisition process of literacy skills is explained below.

The answer to the question of "When are children ready to learn how to read and write?" has been tried to be provided not on the basis of age but on the basis of adequacy of the norms and conditions and usually answered as when the children attain the required physical and mental maturity and level of readiness. The belief imposing that this formal education should be initiated when children are ready for the school has been accepted to be a basic principle, leading to the creation of learning tools (Teale, 1995). School age is widely accepted as 6 years of age, although it varies by culture.

There are various opinions and approaches proposed to explain the language development process experienced by the children from birth to school age, that is, in their early childhood period, before they acquire formal reading and writing skills. The process of acquiring the language skills that the behaviourist approach tries to explain with stimulus-response process ignoring mental phenomena has evolved into a structure that emphasizes the importance of mental impact, especially with the increase of psychological and brain research. Cognitive and socio-cultural views emphasizing the importance of social environment and communication have gained importance. According to this view and his representative Vygotsky, a child learns the language through the meaningful interactions he/she establishes with his/her environment and with the help of the people around his/her.

\section{Emergent Literacy}

The interaction between a child and the environment starts in the family cycle. Researchers have investigated the effect of this interaction on the acquisition of language skills and they have emphasized that the process of language acquisition should be seen as a process starting at birth and that the child learns literacy skills through the interactions he/she establish with his/her environment (Bruner, 1978; Goodman, 1984).

Ege (2007) believes, Van Kleeck and Schule (1987) described this situation as literacy socialization by classifying in three headings which are literacy artifacts, literacy events, and information gained from literacy experiences by children.

Literacy artifacts: In the surroundings of children there are many literacy artifacts such as texts on pillboxes, food packages, newspapers, magazines, books, pictures, and crayons encouraging them to write and scratch papers. Children's interactions with these artifacts bring about various effects on children related to reading and writing.

Literacy events: Literacy events refer to the literacy activities including children's witnessing the literacy events performed by adults and sometimes their involvement in the events. The most important literacy event for children is a reading activity performed by an adult. In this way, children can understand many things ranging from the direction of reading to comprehending the relationship between writing and verbal language.

Information gained from literacy experiences by children: Children growing in a rich environment in written materials start to learn the features of written language at early ages (Van Kleeck \& Schule, 1987).
The children equipped with the early literacy skills through communication or other ways can start elementary education where formal literacy training is accessible. The skills they have acquired in the pre-school period provide them more advantageous over other children (Hood, Conlon \& Andrews, 2008). The children receiving pre-school education also acquire higher literacy readiness skills.

\section{Basic Skills Influential on the Acquisition of Literacy}

Literary skills, namely reading and writing skills, are acquired through complicated mental and physical processes. There are many factors affecting this process. The cognitive process affects the development of the language and the development in the language affects the cognitive skills. During the process of acquiring literacy; children develop themselves in various sub-areas such as phonetics, alphabetic awareness, form-syllable, vocabulary recognition, reading comprehension, and writing skills which will be detailed below

Phonemic Awareness and Auditory-Sensory Awareness Skills. Children spontaneously use several sounds in spoken language. They also use words composing these sounds without knowing and thinking of the meanings of the words. Many usages in a language are automatic for them. Their language develops more in the process of time and they start to acquire skills needed to think about the language to analyse and control its units. All these skills are called metacognitive skills. Metacognitive awareness has a significant effect on the acquisition of the literacy skills (Chaney, 1994).

Phonemic awareness is a skill that affects the acquisition of literacy skill a great deal. This skill involves the recognition of the fact that words are made up of phonemes. The locations of phonemes can change depending on the word in which they are used. The disintegration of words into their phonemes and the generation of words from the given phonemes. Children generally attain phonemic awareness until they are about six years old. The instructions given in this period should particularly emphasize phoneme-letter relationship.

Another basic competence necessary for the acquisition of literacy skill is the auditory-sensory awareness. Knowing and recognizing the letter to a phoneme heard and that letters are visually different from each other is a vital indicator for both reading and writing skills. For instance, it is important to visually distinguish the letters $b$ and $d, s$, and ş. Activities conducted for children to acquire these skills are the main preparatory activities for the literacy teaching (Ege, 2007).

Alphabetic Awareness. Alphabetic awareness refers to the recognition of the letters in the written language corresponding to the sounds in the spoken language. Children discovering the letter-phoneme correspondence know that letters in writing represent phonemes and they start to disintegrate phonemes, re-unite, and replace them (Ehri 2005; Stanovich, 2000). Alphabetic language systems can be formed as overlapping-transparent or non-overlapping-non-transparent. This can be accepted as a source of difficulty or easiness in learning to read and write. Given the fact that Turkish is a language in which letters are written as they are pronounced, phoneme transparently represent the letters. Hence it is safe to say that it is easier to learn Turkish than learning the languages with non-transparent alphabetic systems.

Form-syllable and Word Awareness. Form-syllable awareness is an important skill like phonemic awareness for the development of literacy skills. Syllable awareness involves the recognition of phoneme and morpheme that are the smallest 
units of meaning. Form-syllable awareness involves disintegrating words into syllables and meaningful parts to understand and write the words (Crystal, 1997).

Word Awareness. Words are the most essential structures in a language. Understanding of words in the spoken language is auditory while visual in the written language though a mental dictionary is used to make both of them sense. Recognition of a word is an important higher order linguistic skill to read a word. Children generally read the word by recognizing it entirely. For children, reading on the basis of the analysis of phonemes is a longer and more exhausting process.

Reading Comprehension. It is not enough to have mastered the awareness of voice, syllable, and word in order to acquire all the reading skill. Reading is an action of a completed meaning. Most of the time the reading action is performed to gain knowledge and to make an inference. As a consequence of this fact, it is safe to say that there is no way to complete the act of reading with no comprehension. In addition to the competence mastery of other higher order language skills, reading comprehension also requires affective, cognitive, and metacognitive skills such as motivation, purpose, strategies, and ability to use a strategy.

Writing Skill. Writing skill includes two main sub-skills. Kinaesthetically producing and copying phoneme-letters in a language on a writing tool is the first sub-skill while producing ideas in an organized manner by capitalizing on the possibilities of the written language is the other one.

The formal writing process involves the physical aspects of writing, such as pencil holding, doodling, line studies, direction tracking, creating letters correctly, and leaving appropriate spaces between letters and words. It also comprises the pre-skills acquired before attending the school.

Producing ideas involves an interactive endeavour leading to sharing of emotions, opinions, and knowledge, which is the main objective of writing skill. In writing for the production of ideas, skills such as prior knowledge of students, vocabulary, general command of language, genre knowledge, knowledge of idea organization, and information presentation are required. In the first grade of the primary school, first formal writing skills and then the skills of creating smal texts are imparted to students. As the grade level increases, writing activities should be done in such a way as to contain ideas that require longer concentration and higher comprehension. Students should learn the writing development process. It is a worth-emphasising point that writing is a planned activity requiring both thinking and attention.

\section{Conclusion}

The ways in which reading and writing skills are acquired by children have been examined by educational scientists, psychologists, behavioural scientists, and linguists in different manners. There are plentiful discussions on the matter in the literature. Some argue that language is an acquired behaviour (Skinner, 1957), while some maintain that it is an innate skill and an inborn potential in each child that emerges later on (Chomsky, 1957). Some researchers, on the other hand, emphasize the common points of these two views, stressing that both biological elements, learning, and environmental impacts are influential on the language acquisition (Vygotsky, 1962; 1998).

Some of these opinions are adapted to educational environments from an educational point of view, and reading and writing teaching methods and some in-class activities are shaped in line with these opinions. After the 1980s, the influence of the behaviourist views and methods in litera- cy education have dwindled and they have been replaced by the cognitive and socio-cultural views. Regardless of whether phonics based sentence method or the sentence method is used, the child acquires literacy skills in any case; yet, newer approaches providing more meaningful learning experiences have always been preferred.

Turkey schools used to adopt the sentence analysis (tag) method as the initial literacy teaching instrument under the influence of the behaviourist approach. In early 2000s, the phonics based sentence method was started to adopt under the influence of the constructivist approach. Cursive handwriting was preferred in the writing instruction. As a consequence of the pressure imposed by teachers and parents, cursive writing gave place to print letters and all schools have taken cursive handwriting out of their teaching method. Thus, print letters have been used for few years in writing instruction.

Literacy skills are not just about reading and writing skills. Language is entirely connected with all skill areas and an instructional program cannot be organized without speaking and listening skills. The concept of literacy was originally proposed to emphasize that children have a different process of reading acquisition than adults. In the period of literacy development in children, phoneme, syllable, alphabetical knowledge, and word awareness are important higher language acquisition skills.

As a conclusion, the process of language acquisition in children evolves under the influence of several factors such as maturation, mental and physical development, linguistic development, prior learning experiences, an environment with an enhanced literacy awareness, experiences lived in the stage of the acquisition of basic skills, and social and cognitive support provided by teachers and adults for children in this process.

\section{References}

Atkinson, R. L., Atkinson, R. C., Smith, E. E., Bem, D., J., \& Hoeksema, S. N. (2010). Hilgard's Introduction to Psychology. (Y. Alogan, Çev.). Ankara: Arkadaş.

Bandura, A. (1977). Self-efficacy: Toward a unifying theory of behavioral change. Psychological Review, 84, 191 215.

Bruner, J. S. (1978). The role of dialogue in language acquisition. In A. Sinclair, R. J. Jarvella, \& W. J. M. Levelt (Eds), The child's conception of language (pp. 241-256). New York: Springer-Verlag.

Bruner, J. S. (1984). In Search of Mind: Essays in Autobiography (Alfred P. Sloan Foundation Series) (pp. 183). New York: HarperCollins.

Chaney, C. (1994). Language development, metalinguistic awareness, and emergent literacy skills of 3-year-old children in relation to social class. Applied psycholinguistics, 15(3), 371-394.

Chomsky, N. (1957). Syntactic structure. Mouton.

Chomsky, N. (1967). Recent contributions to the theory of innate ideas. Synthese 17, 2-11.

Crystal, D. (1997). The Linguistic Identity of English-language Dictionaries of Linguistics. Lexicographica, 13, 17-33

Ege, P. (2007). Çocuklarda okuryazarlık gelişimi. Seyhun Topbaş (Ed). Dil ve kavram gelişimi. Ankara: Kök.

Ehri, L. C. (2005). Learning to read words: Theory, findings, and issues. Scientific Studies of reading, 9(2), 167-188. 
Ersanlı, K. (2012). Öğrenmede davranışsal yaklaşımlar. Binnur Yeşilyaprak (Ed). Eğitim Psikolojisi, Gelişim-Öğrenme-Ögretim. Ankara: Pegem.

Gleitman, L. R., Osherson, D. N., \& Liberman, M. (Eds.) (1995). An invitation to cognitive science: Language (Vol. 1). MIT Press.

Greene, H. A., \& Petty, W. T. (1975). Developing language skills in the elementary schools.

Hood, M., Conlon, E., \& Andrews, G. (2008). Preschool home literacy practices and children's literacy development: A longitudinal analysis. Journal of Educational Psychology, 100(2), 252.

Goodman, K. S. (1984). The development of initial literacy. (Eds.). Goelman H, Olberg A, Smith F, Awakening to literacy. Exeter: NH: Heinemann Educational Books.

Maviş, İ. (2007). Çocukta dil edinim kuramları. Seyhun Topbaş. (Ed). Dil ve kavram gelişimi. Ankara: Kök.

Owens, R. E. (2001). Language development: An introduction. Needham Heights; MA: Allyn \& Bacon.

Piaget, J. (1926). The thought and language of the child. Jean Piaget New York: Harcourt, Brace, and Company.

Piaget, J. (1971). Biology and knowledge. An essay on relations between organic regulations and cognitive processes. Chicago: The University of Chicago Press

Piaget, J. (1973). To understand is to invent: The future of education.

Plante, E., \& Beeson, P. (1999). Introductions to the professions of audiology and speech-language pathology. Communication \& communication disorders: A clinical introduction, 1-16.

Puntambekar, S., \& Hübscher, R. (2005). Tools for scaffolding students in a complex learning environment: What have we gained and what have we missed?. Educational psychologist, 40(1), 1-12.

Stanovich, K. E. (2000). Progress in understanding reading: Scientific foundations and new frontiers. Guilford Press.

Skinner, B. F. (1957). Century psychology series. Verbal behavior. East Norwalk, CT, US: Appleton-CenturyCrofts.

Teale, W. H. (1995). Young children and reading: Trends across the twentieth century. Journal of Education, 177(3), 95-127.

Tudge, J., \& Scrimsher, S. (2003). Lev S. Vygotsky on education: A cultural-historical, interpersonal, and individual approach to development. Educational psychology: A century of contributions, 207-228.

Wood, D., Bruner, J. S., \& Ross, G. (1976). The role of tutoring in problem solving. Journal of child psychology and psychiatry, 17(2), 89-100.

Van Kleeck, A., \& Schuele, C. M. (1987). Historical perspectives on literacy in early childhood. American journal of Speech-Language Pathology.

Vygotsky, L. S. (1962). Language and thought. Massachusetts Institute of Technology Press, Ontario, Canada.

Vygotsky, L. (1978a). Interaction between learning and development. Readings on the development of children 23(3), 34-41.
Vygotsky, L. S. (1978b). Mind in society: The development of higher mental processes (M. Cole, V. John-Steiner, S. Scribner, \& E. Souberman, Eds.). Cambridge, MA: Harvard University Press.

Vygotsky, L. S. (1987). Thinking and speech (N. Minick, Trans.). In R. W. Rieber, \& A. S. Carton (Eds.), The collected works of L. S. Vygotsky. Volume 1: Problems of general psychology (pp. 39-285). New York, NY: Plenum Press.

Vygotsky, L. S. (1998). The problem of age. The collected works of LS Vygotsky, 5, 187-206. 